\title{
EFFECTS OF PLANTING DATE ON GROWTH AND FLOWER CHARACTERISTICS OF Zinnia elegans L. UNDER CONDITIONS OF LAHG GOVERNORATE, YEMEN Massoud, $\mathrm{K}$. \\ Dept. of Horticulture, Fac. of Agric, Abstact Lahg, Yemen
}

\begin{abstract}
An experiment was carried out during the successive seasons of $1990 / 1991$ and 1991/1992 at the nursery of Horticulture Dept., Naser college of Agriculture, Lahg, Yemen, to study the effects of three planting date (last week of Sept., last week of Nov., and last week of Jan.) on growth and flower characteristics Zinnia elegans L. under field condition. Results showed that neither plant height not flower head diameter were not affected by planting date however, early (last week of Sept.) and late (last week of Jan.) plantings resulted in better plant fresh weight and number of leaves/plant then medium planting date. Early planting date resulted in heightest fresh weight of flower.
\end{abstract}

\section{INTRODUCTION}

Many agricultural research centers have been recently established in Yemen. The government has paid great interest in spreading information about growing and cultivation of new plants.

On of the most important fields of research is introducing new ornamental plants. Although many ornamental plants grw successfully in Yemen yet they are grown on scientific basis and depends only on individual experience. On the main objects of the horticulture department of Naser college of Agric. is carry on research work on ornamental plants under the local conditions of lahg governorate. The weather of this governorate is suitable for growing annuals, but each plant needs specific information order to actieve the best growth of the plant. In this experiment, Zinnia elegans was tested as a sample annual, the appropriate sowing date in order to achieve better growth and flowering of similar annuals. Yang et al (1998) reported that flowering was delayed if bulbs of lilies were planted in the winter.

\section{MATERIAL AND METHODS}

Three different dates of sowing were tested, last week of September, last week of November, and the last week of January. The experiment was carried out during the successive seasons of 1990/1991 and 1991/1992 at the nurser of the Hor. Dept., Naser College of Agric., Lahg governorate, Yemen. Seeds were sown in soil mix (sand:soil) $(1: 1 \mathrm{~V} / \mathrm{V})$ on each specific date. One month later, seedlings were transplanted to beds $(2 \times 2.5 \mathrm{~m})$ and planted in rows spaced $15 \mathrm{~cm}$ and plants were spaced at $15 \mathrm{~cm}$ apart. Plants were watered regularly and data were collected on height of the plant,weight of the vegetative growth, number of leaves/plant, diameter and fresh weight of the flower head. 


\section{RESULTS AND DISCUSSION}

Data in table 1 show that of though plant height was not of leaves per plant were significantly affected in both seasons. Data clearly show that early and late planting resulted in significantly more weight nd number of leaves then medium date of planting. In addition, early and late planting dates did not significantly differ in either their weights or their number of leaves.

Table 1. Effects of plant spacing on vegetative growth of Zinnia elegans

\begin{tabular}{|c|c|c|c|c|c|c|}
\hline \multirow{2}{*}{$\begin{array}{l}\text { Planting } \\
\text { date }\end{array}$} & \multicolumn{2}{|c|}{ Plant height $(\mathrm{cm})$} & \multicolumn{2}{|c|}{ Plant fresh wt (g) } & \multicolumn{2}{|c|}{$\begin{array}{l}\text { Number of } \\
\text { leaves/plant }\end{array}$} \\
\hline & $\begin{array}{c}1^{\text {st }} \\
\text { season }\end{array}$ & $\begin{array}{c}2^{\text {nd }} \\
\text { season }\end{array}$ & $\begin{array}{c}1^{\text {st }} \\
\text { season }\end{array}$ & $\begin{array}{c}2^{\text {nd }} \\
\text { season }\end{array}$ & $1^{\text {st }}$ season & $\begin{array}{c}2^{\text {nd }} \\
\text { season }\end{array}$ \\
\hline Early & 30.4 & 32.6 & 33.8 & 35.6 & 42 & 45 \\
\hline Middle & 26.1 & 28.2 & 16.1 & 18.3 & 30 & 31 \\
\hline Late & 29.8 & 30.3 & 26.8 & 30.0 & 41 & 45 \\
\hline $\begin{array}{l}\text { LSD } \\
(0.05)\end{array}$ & NS & NS & 7.3 & 7.8 & 3.9 & 4.1 \\
\hline
\end{tabular}

Unlike early and late planting dates, plants sown on the last week of November and transplanted during the last week of December were exposed to colder weather during thing theing juvenile stage than those planted in other two dates. This seewed to have a retading effects of plant growth. Munietal (1997) concluded that on Artemiia annua artemisinin content was dependent on the weather conditions. On the other hand, sown on last week of September and transplanted during October, did not expose to weather of winter until they were old enough to stand the cooled weather of winter, and those of late planting were already transplanted at the beginning of spring season.

Flower head diameter was not significantly affected by planting date. However, this character is a genetic characteristic of the plant and was not greatly affected by the environmental conditions. Singh et al. (1997) reported that on cauliflower transplanting between 25 November and 5 December during 1995 and 1996 achieved the earliest flowering and produced curds of maximum weight and diameter.

The highest fresh weight of the flower head was achieved as a result of early planting date and was significantly more than those of plants sown on the last week on November and May (1998) noted that final marketable yield levels ranged of Brussels sprouts between $29.4 \mathrm{t} / \mathrm{ha}$ when planting was early, to $17.4 \mathrm{t} / \mathrm{ha}$ when planting was late in the season. The fresh weight of the flower heads of plants sown on last week of January were intermediate and was relatively less than those of early plantings relatively more than medium planting date. 
Table 2. Effects of planting date on flower diameter and flower weight of Zinnia elegans L. plants

\begin{tabular}{|c|c|c|c|c|}
\hline \multirow{2}{*}{ Planting date } & \multicolumn{3}{|l|}{ Flower head diameter $\mathbf{( c m )}$} & Flower head fresh weight $(\mathbf{g})$ \\
\cline { 2 - 5 } & $\mathbf{1}^{\text {st }}$ & $\mathbf{2}^{\text {nd }}$ & $\mathbf{1}^{\text {st }}$ & $\mathbf{2}^{\text {nd }}$ \\
\hline Early & 3.4 & 3.5 & 2.2 & 2.2 \\
\hline Middle & 3.5 & 3.5 & 1.3 & 1.2 \\
\hline Late & 3.5 & 3.6 & 1.8 & 1.8 \\
\hline LSD (0.05) & NS & NS & 0.7 & 0.7 \\
\hline
\end{tabular}

\section{REFERENCES}

Everaarts A.P. and C.P. De. Moel (1998). The effect of planting date and planting density on yield and grading of Brussels sprouts. J. Hort. Science and Biotechnology 73(4)549-554.

Muni R., M.M. Gupta, A.A. Nayvi and S. Kumar (1997). Effect of planting time on the yield of essential oil and artemisinin in Artemisia annua under subtropical conditions. J. of Essential Oil Research 9(2) 193-197.

Singh D.B., M.A. Suryanarayana and K. Swaroop (1997). Note on yield and quality on cauliflower var. Best Early as affected by different dates of planting. Vegetable Science 24 (1)75.

Yang CM, L. Yuhjyuan, C. Ayhwa (1998). Influence of planting environment on growth and yield of hybrid lilies III. Climatic effects on growth and flowering in plants from bulbs of different reproduction seasons. Chinese J. Agrometroology 5(1) 37-47.

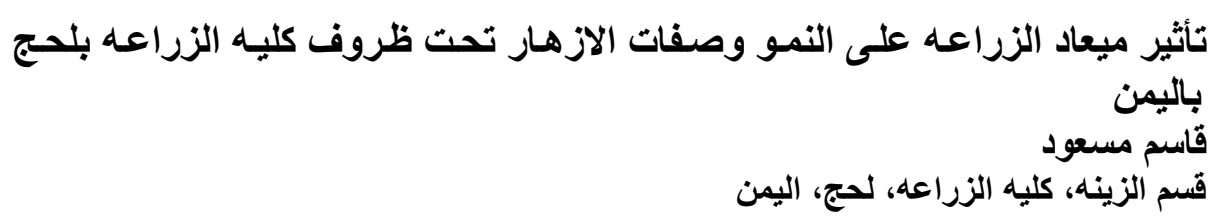

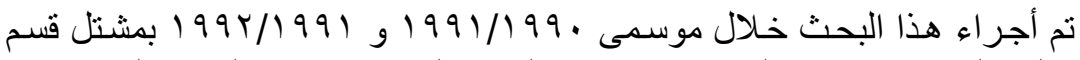

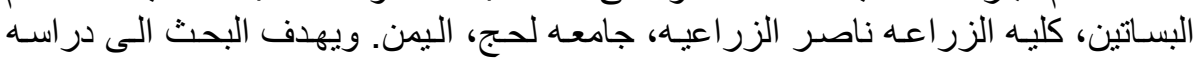

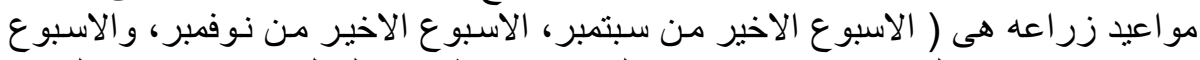

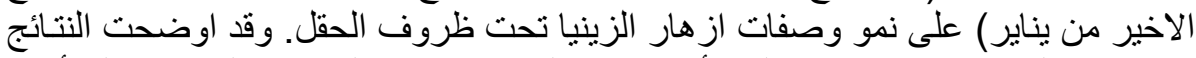

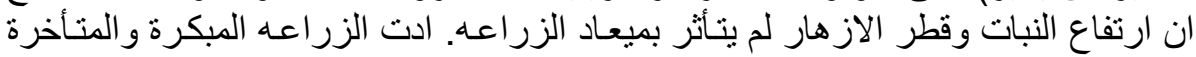

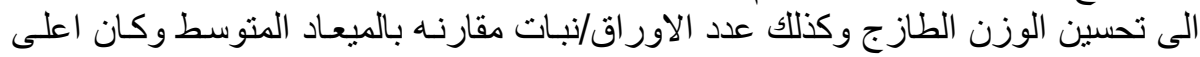

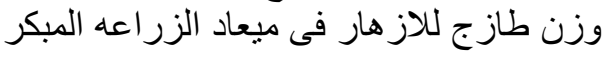

